\title{
Assessing the spatio-temporal pattern of winter sports activities to minimize disturbance in capercaillie habitats
}

\author{
Reto Rupf, Martin Wyttenbach, Daniel Köchli, Martina Hediger, Salome Lauber, Pascal Ochsner \& Roland Graf \\ Keywords: GPS logging, backcountry skiing, snowshoeing, Tetrao urogallus, wildlife management, visitor management, recreation \\ ecology, human wildlife conflict, Val Müstair Biosphere Reserve
}

\section{Abstract}

Outdoor activities may have serious consequences for wildlife species that are sensitive to human disturbance. The pressure of outdoor activities on natural landscapes has increased dramatically in recent decades. However, we generally lack information on the spatial and temporal patterns of outdoor activities - a fact that makes it difficult to quantify the impact on wildlife and thus to implement and justify measures to constrain outdoor activities.

In the winter seasons 2008/2009 and 2009/2010, we equipped 303 recreationists in the Val Müstair Biosphere Reserve, eastern Swiss Alps, with GPS loggers to record their spatial and temporal pattern of landscape use. We then analysed how the resulting pattern of spatial use overlapped with the habitat of capercaillie Tetrao urogallus, an endangered woodland grouse species that is highly sensitive to disturbance. For our study we used the official capercaillie core winter habitats observed by the game wardens of the Canton Grisons.

The recorded 319 trips of 188 backcountry skiers and snowboarders and 231 trips of 115 snowshoers combined show an inhomogeneous use of subareas in the region. With one exception, the trips are located in the main valley and the adjoining southern and northern slopes and peaks. The trips of snowshoers result in a dispersed use pattern across the main valley, while the trips of the backcountry skiers and snowboarders are concentrated more on official and popular routes. Rarely did recreationists trespass official wildlife sanctuaries or cross capercaillie habitat patches.

However, one official, very popular backcountry skiing route crosses one of the largest capercaillie habitats. Here the recorded trips show wide-ranging spatial use with many connectors to the main route. As a consequence, this capercaillie habitat patch is dissected into smaller undisturbed patches.

GPS logging in combination with camera trap data provides detailed information on the spatio-temporal land-use pattern of outdoor activities. Based on these data, we identified a conflict of interest in the Val Müstair Biosphere Reserve that has to be resolved by management in a joint participatory process with the main stakeholders. Our methods and results could be transferred to other Alpine regions and be used for any land cover types. In this way we hope to contribute to mitigating conflicts between human outdoor activities and wildlife populations.

\section{Profile}

Protected Area

Val Müstair Biosphere Reserve

Mountain range

Alps

Country

Switzerland

\section{Introduction}

Changes in recreational behaviour and population growth have increased the pressure on nature in $\mathrm{Al}$ pine regions and their wildlife. Especially in winter, outdoor sports activities such as backcountry skiing and snowshoeing cause difficult conditions for wildlife species (Ingold 2005).

In the Alps, snowshoeing is one of the fastest growing outdoor sports activities. Sales of snowshoes in Switzerland increased from 3000 pairs in the winter 1999 / 2000 to 75000 pairs in $2005 / 2006$. Forecasts predict a market of up to 325000 pairs a year (Walter 2010). In Austria, Germany, Italy or Switzerland, the market is set to grow in the coming years (Schnee-
schuhprofi-Akademie 2007). This development is identified by other authors as well (Zeidenitz 2005; Radue 2004). A similar development has been identified for freeriding, or off-piste skiing and snowboarding. In some winter sports resorts, off-piste skiing is very popular with about $50 \%$ of the skiers. These figures are endorsed by sales figures of sports retailer VölklSwitzerland, where $50 \%$ of the ski sales are off-piste skis (Loppacher 2008; Neue Zürcher Zeitung 2007).

The five top reasons for doing sports are maintaining health, having fun, relaxing, getting away from everyday life and fitness (Lamprecht et al. 2008). Backcountry skiers' main motivations are experiencing nature, recreation and relaxation, a sporting challenge or seeking solitude and silence (Sterl et al. 2010). 


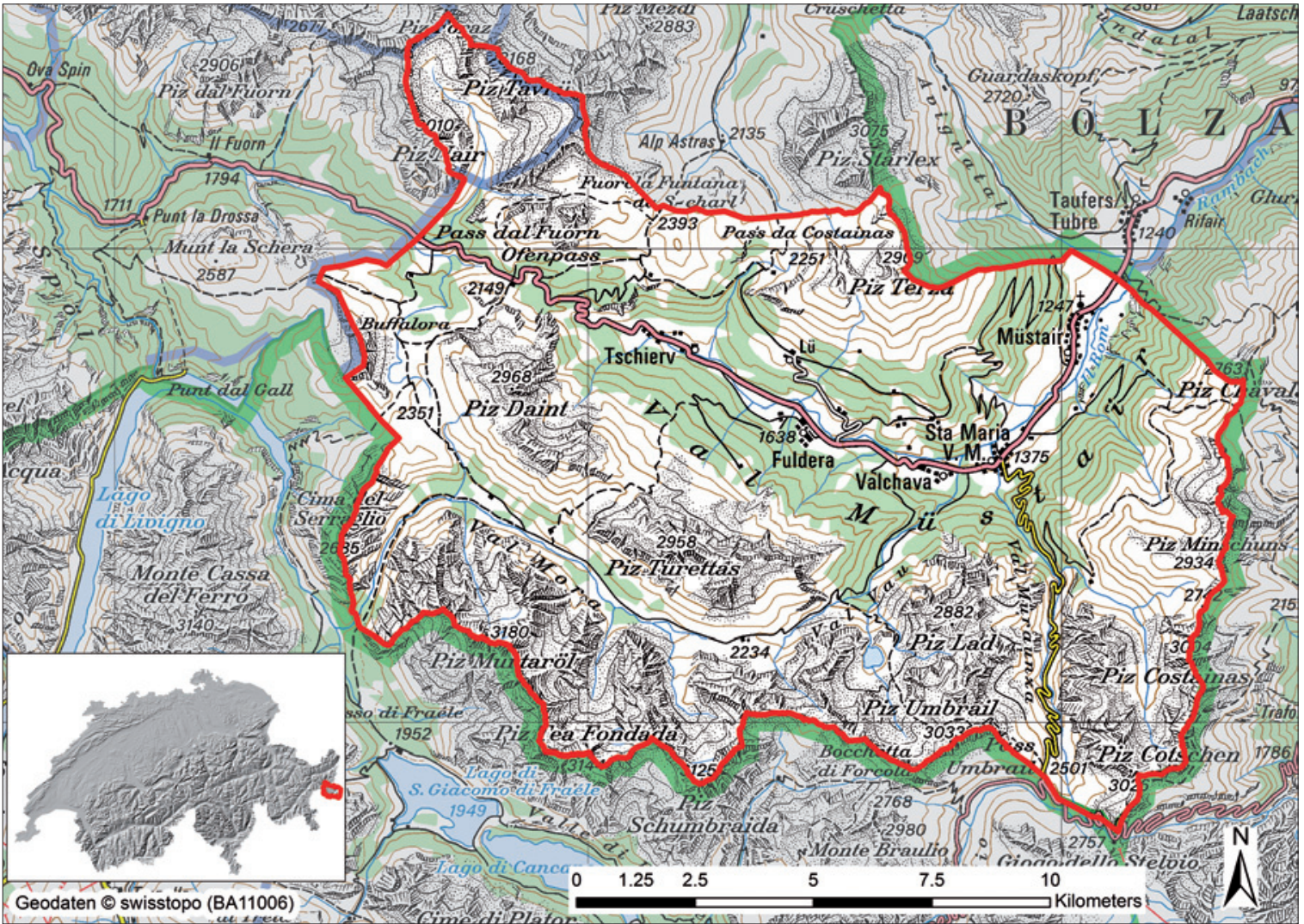

Figure 1 - Val Müstair Biosphere Reserve.

As a result of these motivations and activities, recreation affects more and more areas and is triggering various conflicts. In terms of sports-nature interactions in forests of mountain regions, forest experts ranked backcountry skiing and snowshoeing as having the highest conflict potential (Freuler 2008). Outdoor activities affect wildlife in various ways. In general, wild animals react to approaching humans rather like they do when confronted with a predator (Beale \& Monaghan 2004), i.e. they hide or fly away. In either case they may show a stress reaction and/or change their spatio-temporal habitat use. All these reactions may affect the animal's tight energy budget during the winter season, impair its overall condition with consequences for survival and reproduction and directly increase mortality (Ingold 2005). Frequent disturbance of individuals can also evoke a response at population level, i.e. cause a decline in population (e.g. Müllner et al. 2004). Intensive tourist land use by ski-runs can cause a loss of bird biodiversity or bird numbers on the pistes and in nearby areas (Laiolo \& Rolando 2005; Rolando et al. 2007).

Wild animals may get used to frequent, regular and predictable activities but not to unpredictable and sudden disturbance events (e.g. Whittaker \& Knight 1998; Ingold 2005). Therefore, they can hardly adapt to snowshoe and backcountry skiers who are moving off-trail and may appear at any time of day.

European grouse species are highly susceptible to human disturbance. For capercaillie Tetrao urogallus (Thiel et al. 2008) and black grouse Tetrao tetrix (Arlet- taz et al. 2007), higher concentration of faecal stress hormone metabolites (corticosterone) were measured after disturbance. When frequent disturbances keep stress hormone level high for a longer period, physiological and immunological consequences can be expected (Sapolsky 1992). There is also evidence that a high frequency of disturbance affects habitat use of capercaillie (e.g. Thiel et al. 2008) and may cause a decline in population (Brenot et al. 1996). Population density of Black grouse was lower in areas with ski resorts than in areas without human infrastructure (Patthey et al. 2008). Unpredictable off-trail winter sport activities thus are a new serious threat for grouse species (Arlettaz et al. 2007).

Capercaillie is a large woodland grouse species with specialized habitat preferences and high spatial demands. These characteristics make it a suitable umbrella species for other typical species of the mountain range (Suter et al. 2002). In recent decades, capercaillie populations in Central Europe have decreased severely and many peripheral habitat patches at lower altitudes have been abandoned (Storch 2000). This is also true of Switzerland, where capercaillie is classified as an endangered species with high priority for conservation (Mollet et al. 2008). Given the current low level of capercaillie populations, all existing populations must be preserved, encouraged or at least protected from increasing negative impacts, e.g. disturbances by outdoor activities. However, in many cases it is not possible to define entire capercaillie habitat patches (landscapes) as wildlife sanctuaries without triggering 
opposition by the residents. In such situations, detailed information on the spatial and temporal distribution of outdoor activities is important to define spatially explicit management actions to minimize the impact on local capercaillie populations.

In its statutory framework, UNESCO established functions for biosphere reserves (UNESCO 1996). These reserves are seen as sites of excellence in conservation and sustainable development. In the municipality of Müstair, the south-eastern buffer zone of UNESCO biosphere reserve Val Müstair - Parc Naziunal, general knowledge about the use and requirements of outdoor recreationists exists but detailed information on the spatial and temporal pattern of these activities is not available. Therefore, we lack information for identifying potential zones of human-wildlife conflicts in a spatially explicit way. We developed a novel method to measure the spatio-temporal land use pattern of off-piste winter sports activities and tested its usefulness in Val Müstair Biosphere Reserve (BR) to obtain sound data for minimizing disturbance in capercaillie habitats. In particular, we:

- assessed and analysed the spatial and temporal land-use pattern of backcountry skiers and snowshoers in the Val Müstair BR on the basis of data captured with newly developed GPS loggers and digital camera traps;

- identified and quantified the capercaillie habitats affected by backcountry skiers and snowshoers;

- suggest management actions to reduce the impact of winter sports activities on local capercaillie populations.

\section{Methods}

\section{Study area}

The Val Müstair $\left(46^{\circ} 36^{\prime} \mathrm{N}, 10^{\circ} 22^{\prime} \mathrm{E}\right)$ with its 1608 inhabitants is situated on the periphery of the eastern Alps of Switzerland, on the border with Italy, and covers an area of $198.6 \mathrm{~km}^{2}$ (Amt für Wirtschaft und Tourismus Graubünden 2011) (Figure 1). The municipality of Val Müstair was created in 2009 from originally six small municipalities with their villages in the main valley: Müstair (1250 m), St. Maria, Valchava, Fuldera, Tschierv and Lü $(1910 \mathrm{~m})$. Due to its position in the inner Alps, surrounded by high mountain ranges (highest peak in Val Müstair $3180 \mathrm{~m}$ ), the climate is quite continental with $690 \mathrm{~mm}$ precipitation in Müstair. $28.8 \%$ of the area is used for farming, $25.7 \%$ is forest, $1 \%$ settlement area and $44.5 \%$ is unproductive land (Amt für Wirtschaft und Tourismus Graubünden 2011). The Val Müstair has a traditional cultural landscape with a high proportion of natural habitats that provide suitable conditions for a number of animals, such as red deer (Cervus elaphus), chamois (Rupica prarupicapra) and different grouse species that are sensitive to human disturbance. These characteristics, combined with the proximity to the Swiss National Park qualify the entire region as a UNESCO biosphere reserve.
The marvellous landscape, diverse outdoor sports options and the communications by the Val Müstair BR have increased the annual overnight stay figures from 86500 (1998) to 138000 (2008). Additional guests are day visitors from the surrounding areas of Engadin, Italy and Austria. Main attractions are the UNESCO World Heritage Convent of St. John as well as the nature and outdoor sports options.

Main objectives of activities in the area are protecting the valuable landscape and wildlife of the region, plus attracting new visitors and more income for residents (Biosfera 2008). However, the rising number of visitors also increases the potential for conflict (e.g. Sterl 2010; Ingold 2005). Therefore the park managers of Val Müstair BR need more information about the behaviour of their recreationists.

\section{GPS logging campaigns}

GPS monitoring is a method with new perspectives to collect real spatial and temporal movements as revealed preference data (e.g. Taczanowska et al. 2008; Warnken \& Blumenstein 2008; Marwijk et al. 2007; Skov-Petersen 2005). To reveal spatial data of backcountry skiers and snowshoers in the Val Müstair, we logged the trips of 303 recreationists with GPS during winter seasons 2008/2009 and 2009/2010. At popular tour starting points like Buffalora, Tschierv, Fuldera, Lü, Santa Maria and Müstair, in hotels and shops, we informed recreationists about the scope of the GPS logging to assess their requirements and behaviour and asked them to capture research data by carrying a GPS logger during their recreational activities. Overall $90 \%$ of the recreationists approached accepted the request and carried a logger on their trips during their entire stay in Val Müstair BR. More than $55 \%$ of them carried the logger for three days of sports activities and more. Thus we assume that we could record a relative distribution of the backcountry skiing and snowshoe tours in the study area.

In addition to the GPS logging, the participants kept a diary about their tour data (point and time of entry, type of sports activity, destination, group size, role in group, with or without dogs) and personal data (name, address, contact information), socio-demographic data (age range, gender), and visitor-related data (transportation, kind and length of stay). This information was later linked to the corresponding GPS track as additional attribute data.

\section{GPS logger}

Our GPS logging required a device with adequate accuracy, long runtime, corresponding integrated memory and a small, rugged and moisture-proof case. Data capture should not influence the recreationists' behaviour. As there was no such device on the market, we initiated the development of a new GPS logger by Art of Technology, Zurich.

Our GPS logger delivers a horizontal positional accuracy of about $4 \mathrm{~m}$ in open areas, less under inferior 
Table 1 - Land use of winter sports activities and capercaillie core habitats.

\begin{tabular}{|l|r|r|}
\hline Area & Area [ha] & [\%] \\
\hline Total study area (municipality of Val Müstair) & 19867 & 100.0 \\
\hline Area used by skiers and snowshoers (buffer 100 m) & 6411 & 32.3 \\
\hline Area used by skiers (buffer 100 m) & 5269 & 26.5 \\
\hline Area used by snowshoers (buffer 100 m) & 4054 & 20.4 \\
\hline Capercaillie core habitats Val Müstair & 936 & 4.7 \\
\hline Capercaillie core habitat patch Piz Dora (number 3) & 246 & 1.2 \\
\hline
\end{tabular}

Table 2 - Affected areas and capercaillie habitats by winter sports activities.

\begin{tabular}{|l|c|c|c|c|}
\hline \multirow{2}{*}{} & \multicolumn{2}{|c|}{$\begin{array}{l}\text { Capercaillie core habi- } \\
\text { tats Val Müstair }\end{array}$} & \multicolumn{2}{c|}{$\begin{array}{l}\text { Capercaillie core habi- } \\
\text { tat Piz Dora (number 3) }\end{array}$} \\
\cline { 2 - 5 } & {$[$ ha] } & {$[\%]$} & {$[$ ha] } & {$[\%]$} \\
\hline Total habitat area & 935.6 & 100 & 245.6 & 100 \\
\hline Undisturbed & 657.9 & 70.3 & 82.6 & 33.6 \\
\hline Affected by skiers and snowshoers & 277.7 & 29.7 & 163.0 & 66.4 \\
\hline Affected by skiers & 227.8 & 24.4 & 151.2 & 61.6 \\
\hline Affected by snowshoers & 152.4 & 16.3 & 92.7 & 37.7 \\
\hline
\end{tabular}

Table 3 - Intensity of impact on capercaillie core habitats by winter sports activities.

\begin{tabular}{|l|c|c|c|c|}
\hline \multirow{2}{*}{ Intensity $\left[\mathbf{k m} / \mathbf{k m}^{2}\right]$} & \multicolumn{2}{|c|}{$\begin{array}{l}\text { Capercaillie core habitats } \\
\text { Val Müstair }\end{array}$} & \multicolumn{2}{c|}{$\begin{array}{l}\text { Capercaillie core habitat } \\
\text { Piz Dora (number 3) }\end{array}$} \\
\cline { 2 - 5 } & {$[\mathbf{h a}]$} & {$[\%]$} & {$[\mathbf{h a}]$} & {$[\%]$} \\
\hline Total & 935.6 & 100 & 245.6 & 100 \\
\hline None & 657.9 & 70.3 & 82.6 & 33.6 \\
\hline Weak & 131.5 & 14.1 & 72.1 & 29.3 \\
\hline Medium & 110.6 & 11.8 & 59.4 & 24.2 \\
\hline Intense & 35.6 & 3.8 & 31.5 & 12.8 \\
\hline
\end{tabular}

conditions. The measure interval was set to 5 seconds and could be adjusted down to 0.4 seconds. The rechargeable battery lasts up to 50 hours. However, the overall runtime can be extended to up to ten days by an integrated motion sensor, which switches the logger to standby if it is not moved for two minutes. The integrated $4 \mathrm{MB}$ flash memory stores up to 150000 GPS points. To get optimum satellite signals, it is essential to wear the logger in a high and uncovered position, i.e. on a helmet or on the top of a backpack.

Assessing the frequency of activities with camera traps

In addition to logging individuals, we collected quantitative data by means of digital infrared (IR) trigger cameras. They operate with IR motion sensors and are mostly used for wildlife observation. Adapted to visitor monitoring, trigger cameras can register and count individuals and groups (Warnken \& Blumenstein 2008). Moreover, trigger cameras deliver useful information about direction, individual activity and the group (Bollmann 2010). One drawback is the potential for violating privacy laws (producing images that allow the identification of people) (Warnken \& Blumenstein 2008). To affirm privacy, we blurred the images and explained the purposes of the camera with project and contact information.

To quantify the frequency of backcountry and snowshoeing routes, we placed three cameras (Reconyx Rapid fire HC600) at three spots in the Val Müstair in the winter season $2010 / 2011$. If an individual triggered the camera by passing by, the camera took three photographs at an interval of one second. This enabled us to count all passing individuals manually and to identify their activities.

Combining individual GPS loggings with camera trap data at given points allowed us to estimate absolute numbers of recreationists at any point in time and space throughout the study area.

\section{Capercaillie distribution data}

The cantonal hunting and fisheries agency provided us with survey data of capercaillie that represent the core habitat patches of the capercaillie winter and spring distribution. These patches include all areas with regular presence of capercaillie in winter and spring, based on data originating from systematic surveys by professional game wardens and from occasional evidence found by game wardens, forestry staff or hunters (Gadient et al. 2010). In late winter, until the start of vegetation growth, indirect evidence (mainly faeces) of capercaillie can easily be found at typical habitat features such as roosting, lekking trees or low-branched trees. The faeces can be attributed to season by changes in shape and colour as the birds switch from a winter to a spring diet.

In winter, capercaillie use smaller home ranges than during summer (Storch 1995; Thiel et al. 2008). Therefore, the winter distribution of a local population concentrates on relatively small core areas. These core areas are crucial for the survival of the population and should therefore be kept free from human disturbance and other threats. A comparison of the observed core habitat patches with a statistical species distribution model (Graf et al. 2006) further confirmed the reliability of the data we used for this paper. The core habitat patches overlap largely with the main suitable habitat patches identified by the model. As an exception, the winter habitat of capercaillie in the Val Müstair (observed in the field) included areas at the upper tree line up to $2200 \mathrm{~m}$ - a fact that is particular to this region and therefore not represented by the more general model.

\section{Spatial analysis}

We used ArcGIS 9 for spatial analysis. GPS tracks and official routes were used as vector line data. All other data were converted into raster (cell size $25 \mathrm{~m}$ ).

To calculate the total area of capercaillie core habitats affected by snowshoe and backcountry ski / snowboard tours within the extent of the Val Müstair community, we applied a buffer of $100 \mathrm{~m}$ around the GPS tracks. This buffer distance is justified because animals normally perceive a source of disturbance long before they decide to flee (Ingold 2005). Flushing distances between 10 and $100 \mathrm{~m}$ have been recorded for capercaillie in Switzerland (Thiel et al. 2007).

To estimate the relative distribution of spatial land use by recreationists (i.e. frequency of activities at eve- 


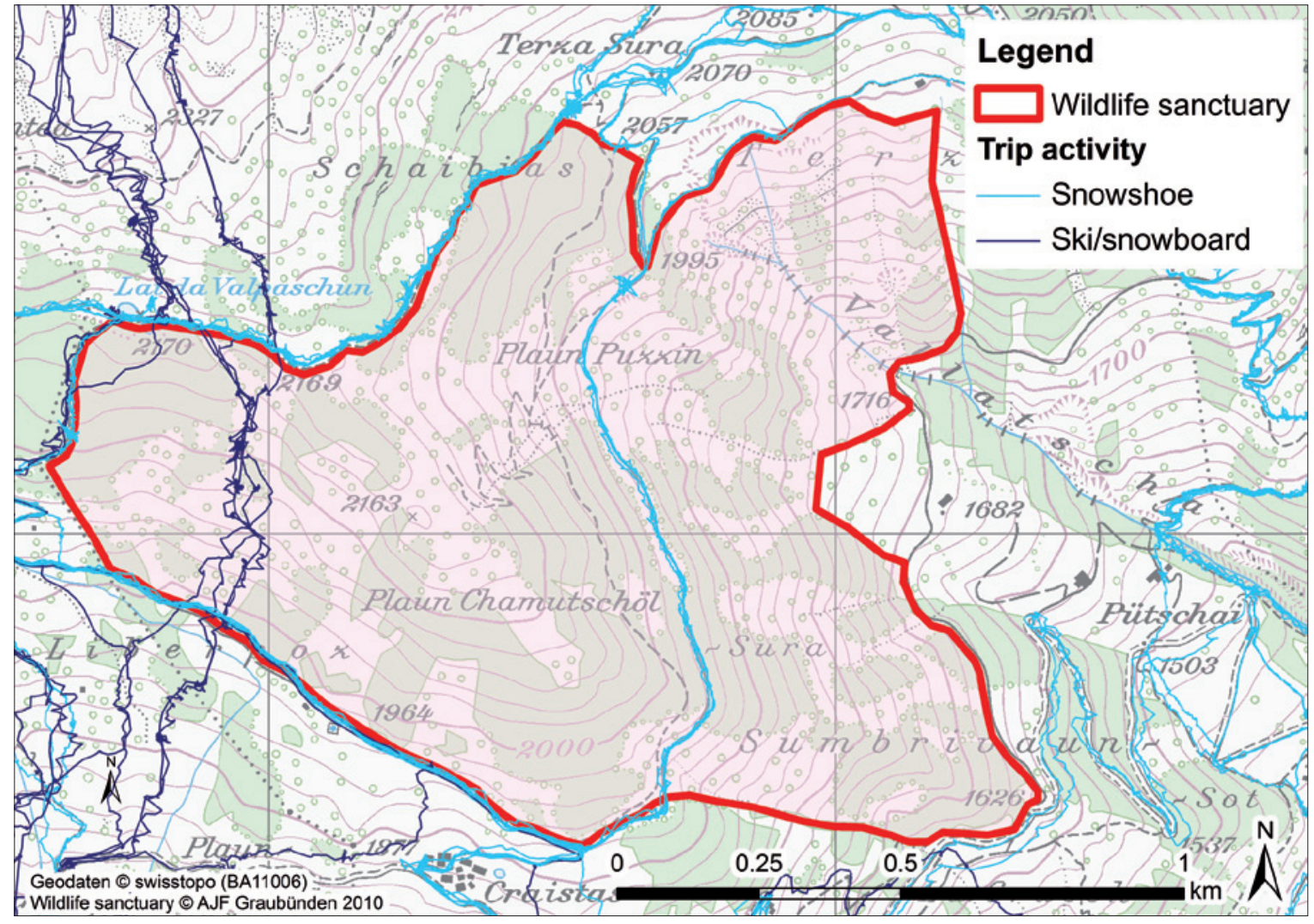

Figure 2 - Conflicts in the area of the wildlife sanctuary Plaun Chamutschöl - Sumbrivaun Sura: five trips crossed the sanctuary illegally on the western part in the wide forest area. Using the forest track to cross the sanctuary is allowed (snowshoe trips).

ry location in the landscape), we calculated a line density: for each raster cell, we calculated the density of GPS tracks within a range of $100 \mathrm{~m}$ (measuring unit: $\mathrm{km} / \mathrm{km}^{2}$ ). A straight crossing through the density extent of one raster cell is $200 \mathrm{~m}$ (equalling a density of $0.2 \mathrm{~km} / 0.0314 \mathrm{~km}^{2}$ ). However, if a person was roaming or went in loops, the total GPS track length of one crossing increased. For calculations, we ignored such patterns, thus getting maximum numbers of crossings.

Combining data from GPS tracking and camera traps, we then translated the relative densities of winter sports activities (GPS tracks) into absolute numbers to get a classification of disturbance levels over the whole logging period. To this end, we carried out the following three steps: first, we divided the total GPS track length per raster by $200 \mathrm{~m}$ to get the maximum number of crossings around the raster in a range of $100 \mathrm{~m}$. Second, we extracted the number of recreationalists from our camera trap, situated at the main tour entry point for Piz Dora (north of patch). Then we counted the number of GPS tracks passing through the camera trap location.

With an average count of 69 recreationalists per week (camera trap data) and a total amount of 70 GPS tracks passing through the camera trap location, our line density from GPS track data represents an average number of crossings per week. Third, we subdivided line density into four different levels of disturbance (crossings per week):
1) not affected $=$ no crossings at all;

2) low $=1$ to 3 (includes single trips with roaming patterns);

3) medium $=4$ to 24 ;

4) intense $=25$ and more.

\section{Results}

\section{GPS logging}

The readiness to wear a GPS logger was surprisingly high with a refusal rate below $10 \%$. During the logging period 2009 (mid-February to mid-April) and 2009 / 2010 (20 December to mid-April), we recorded a total of $550 \mathrm{ski} /$ snowboard or snowshoe trips of 303 individuals. 188 ski / snowboarders generated 319 trips and 115 snowshoers generated 231 trips. Random interviews with backcountry skiers and snowshoers who participated in the GPS logging revealed that experiencing their activity took precedence over the awareness of being tracked. Moreover, the small size, light weight and inconspicuous colour of the GPS unit often made participants forget that they carried a GPS unit at all. We therefore assume that the participants were not influenced by the GPS unit during their recreational activity. Occasional illegal entry or crossings of wildlife sanctuaries (see Figure 2) by the participants support our assumption. 


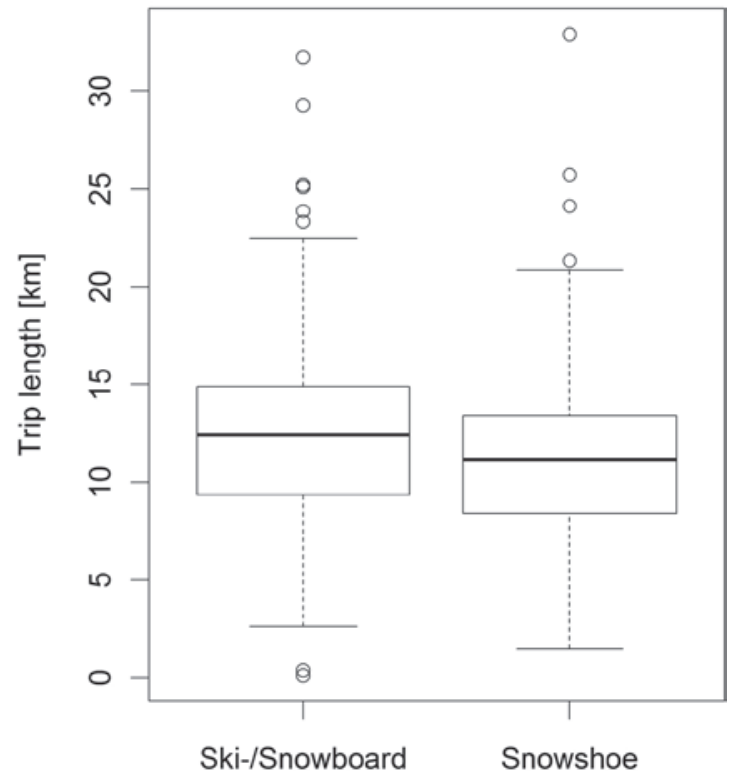

Figure 3 - Comparison of trip length of the different winter sports activities. The boxplots indicate median values, quartiles and outliers (ski/ snowboard: $n=319$ trips, snowshoe: $n=231$ trips).

Spatial and temporal distribution of winter sport activities

GPS data allow exact descriptions of recorded trips. Trends and characteristics of activities can be identified (e.g. Taczanowska et al. 2008; Warnken \& Blumenstein 2008; Marwijk et al. 2007). Ski / snowboard trips are more peak-oriented than snowshoe trips. Snowshoe trips are often shorter than ski / snowboard trips (Figure 3; Wilcoxon Signed Rank Test, W $=44395$, $\mathrm{p}<0.001)$. About a third of the overall study area is used by backcountry skiers and snowshoers (Table 1). With $1.59 \mathrm{ha} / \mathrm{km}$, snowshoe trips affect a larger area than ski/snowboard trips $(1.3 \mathrm{ha} / \mathrm{km})$, which are more likely to follow the same track, especially during ascent.

Out of 550 recorded ski/snowboard and snowshoe trips, Munt Buffalora (74 ascents) was the most frequented, followed by Piz Dora / Piz Turettas (70 ascents), a route that crosses a capercaillie core habitat. We recorded only one person who crossed the Val Mora, a very remote and poorly accessible area in the south-western part of Val Müstair (Figure 4). Other popular peaks are Piz Daint (54 ascents) and Piz Terza (51 ascents). On the route to Piz Dora, we counted an average crossing rate of 69 individuals per week during winter season 2010 / 2011 with a trigger camera.

Figure 5 shows that the official and recommended ski/snowboard routes do not always correspond to the main ski / snowboard ascent routes. Here there is room for improvement by correcting routes or optimizing visitor flow. The accumulation of GPS lines on the main ascent routes indicates that the majority of skiers / snowboarders and snowshoers stay on the same track during their activity.
Spatial overlap of winter sports activities with capercaillie habitats

Capercaillie core habitat patches cover only about $5 \%$ of the total study area (Figure 4 and Table 1). About one third of this area is at least occasionally disturbed by winter sports activities (Figure 4). Most of the capercaillie patches are barely affected by winter sports activities, especially those protected as wildlife sanctuaries. However, the second largest patch (core habitat Piz Dora, patch number 3 ) is severely affected and substantial parts of the area are disturbed regularly (Tables 2 and 3, Figure 5). Given the current pattern of outdoor activities, we have to assume that this capercaillie habitat patch is dissected into smaller undisturbed patches. Otherwise, capercaillie staying in zones of regular disturbance may face a loss of fitness, e.g. by reduced reproductive success.

\section{Discussion}

\section{GPS logging}

During the GPS logging campaign we faced the problem of getting a proper stratified sample. Because of the limited numbers of GPS loggers (40) and of backcountry skiers/snowboarders and snowshoers, we decided to go for as many participants as possible. Therefore we asked every suitably equipped recreationist to carry a GPS logger on their trip. Would people behave differently if they carried a logger? Several facts make us confident that we monitored the normal behaviour of the people: low refusal rate, guarantee of discretion, high number of people logged, a high proportion of people who carried the logger for more than one day, as well as the unattractive appearance of the GPS logger without a display which could have been an attraction for some people. The last two facts were novel compared to other studies (e.g. Marwijk et al. 2007) and provided more information about people's behaviour during an entire stay in a destination (which we have not presented in the context of this paper).

Combining the spatio-temporal data collected with GPS loggers across the entire municipality Val Müstair with the counting data from camera traps provided us with detailed information on the relative importance of different routes, on route constancy and absolute numbers of the frequency of outdoor activities. Braunisch et al. (2011) used aerial photographs and statistical modelling to record and predict conflict zones between winter sports activities and black grouse (Tetrao tetrix). In accordance with the habitat requirements of their target species, they focused on the zone at and above the upper tree line. For two reasons, this approach was not an option for our purposes. First, we needed metadata from the recreationists, e.g. group size, behaviour during their stay, preferences for transport and accommodation. Such data are important to work out management measures. Second, we needed information on the land-use pattern from the valley 


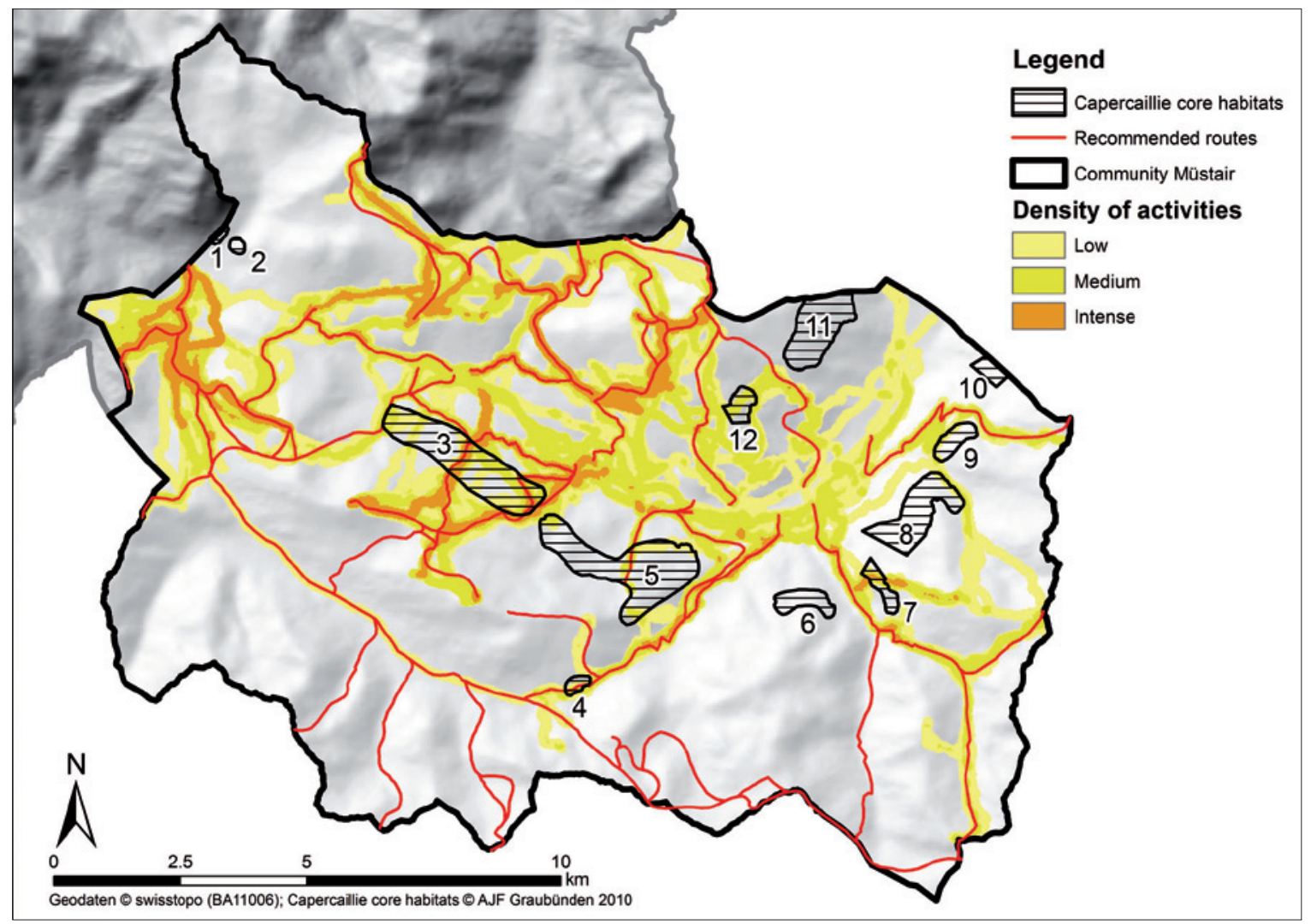

Figure 4 - Density of land use by backecountry skiing, snowboarding and snowshoeing in Val Müstair.

bottom, through the forest belt, up to the summits. At least in dense forests, aerial photographs would not show snow tracks.

\section{GIS analyses}

We found shorter trip length for snowshoers than for backcountry skiers but more land use for snowshoe trips per kilometres than for skiing trips. A reason for this finding could be that skiers follow the same tracks in ascents whereas snowshoers may prefer drawing new tracks in the snow, similar to the widespread descents of skiers and snowboarders.

Many wildlife sanctuaries were created in the canton of Grisons without detailed information on the spatial behaviour of human visitors. Field experience of game wardens, hunters or local wildlife experts, based on visual observation and snow tracks in winter, had to suffice for this process. This may work in an area with a strong lobby for wild animals, but fails in other regions with different population structures. Here game wardens may become scapegoats for constrictions of outdoor activities, when they are always the ones to report on human-wildlife conflicts and claim new wildlife sanctuaries (Robin et al. 2010). In such situations, detailed data on outdoor activities, based on an independent and reproducible assessment, are an inevitable prerequisite for mediating human-wildlife conflicts.

Capercaillie have specialized habitat preferences, therefore the core areas of capercaillie distribution cover only a small proportion of the entire study area.
As capercaillie is currently at a low population level, all local populations should be preserved and even supported. The land-use pattern of outdoor activities in the Val Müstair suggests that a large proportion of capercaillie habitat patches are almost unaffected by winter sports activities. Conversely, the second largest patch is strongly affected and even cut into smaller patches by regular crossings by ski- and snowboard tours and snowshoers. In such a situation, we have to assume a clearly negative effect on the development of the local capercaillie population (Brenot et al. 1996). Thus, our results allow for spatially explicit identification of conflict zones where management actions are needed.

\section{Management implications}

The results of our study imply a range of measures and actions at different management levels. First of all we discussed the situation at the capercaillie core habitat below Piz Dora (patch number 3, Figure 5) with the managers of Val Müstair BR. As the ones responsible for securing sustainable development of the biosphere, the managers involved all stakeholders to consider the priorities of land use - important and popular backcountry route and important core habitat for capercaillies and other species. The discussion resulted in the decision to establish a new wildlife sanctuary with a route corridor. Communicating the new and the existing wildlife sanctuaries and their exact boundaries is essential and challenging, too, because 


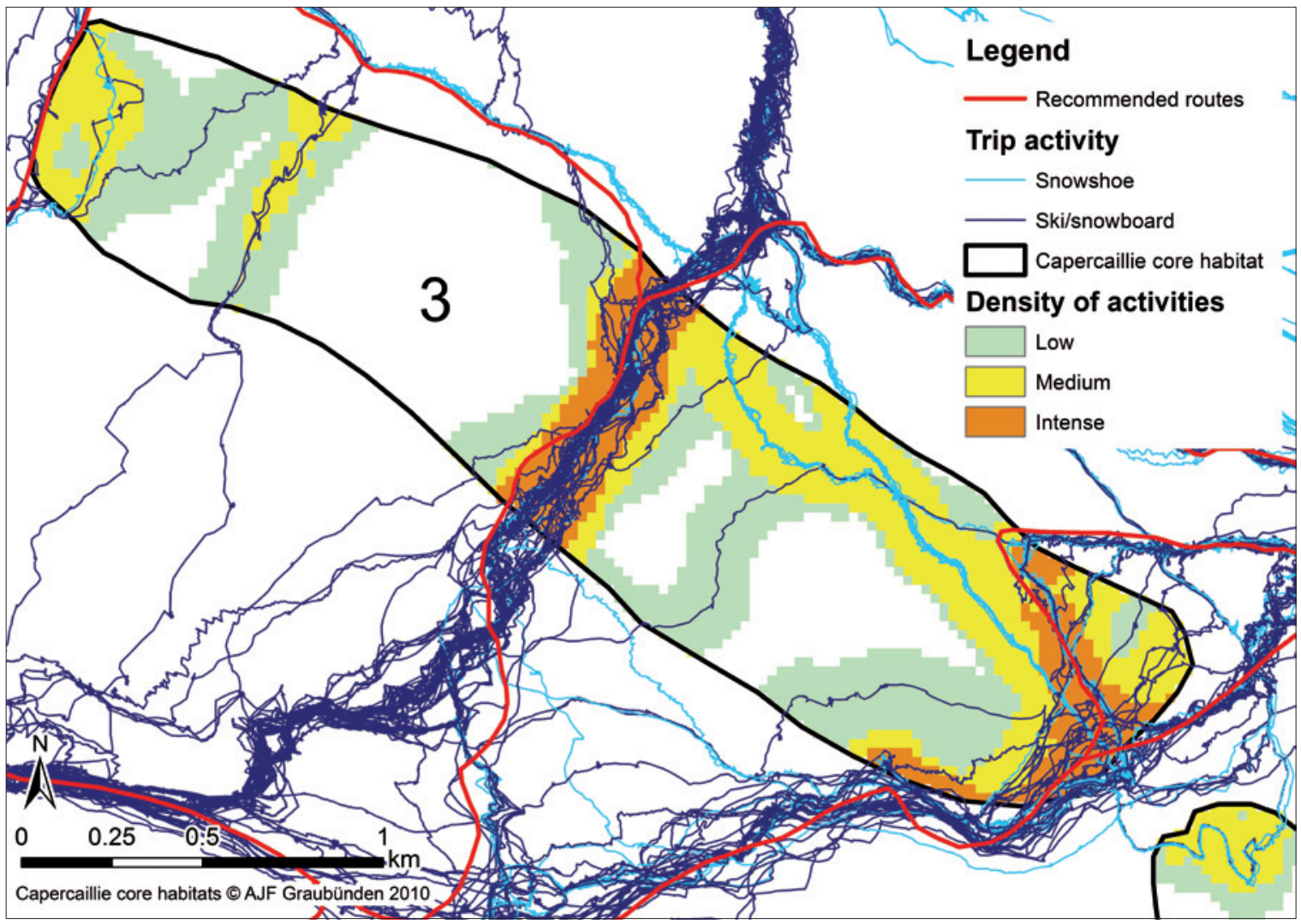

Figure 5 - Density of winter sports activities in capercaillie core babitat Piz Dora (3) as a measure of disturbance.

of the many different starting points of the tours. The spots located by GPS logging will help to develop the necessary actions (Sterl et al. 2010; Freuler \& Hunziker 2007; Mönnecke et al. 2005 and an accompanying questionnaire of this study). Marking routes in the countryside - as many as needed, as few as possible - will be a delicate balancing act. Further monitoring will help to find the right dosage. A combination of comprehensive communication, explanation and control of the wildlife sanctuaries should greatly reduce the disturbance to capercaillie.

Our findings also have consequences for planning large protected areas such as biosphere reserves, nature parks etc. The results and the methods we employed deliver an essential basis for fostering the sustainable development of an area. They suggest that it be divided into subareas with different land-use priorities, to a greater extent than the existing legal rules demand.

Another issue, independent of the existence of protected areas, is the planning and publication of official backcountry skiing and snowshoeing routes. The planners of Alpine clubs and destinations have to tale into account that with a route you do not just publish a corridor of land use but you reserve an area for recreation that might be an essential wildlife habitat.

\section{Acknowledgements}

The presented study and results are a part of the project "mafreina - management toolkit recreation and nature". We want to thank all the project partners for the excellent collaboration and financial support: Canton Grisons, Val Müstair BR, Swiss National Park, Rapp Trans AG, Impuls AG, armasuisse, Art of Technology and Ulrike Pröbstl, Wolfgang Haider and Hans Skov-Petersen.

The project is mainly funded through the Swiss commission of technology and innovation. The game and fisheries agency of the canton of Grisons provided us with data on capercaillie distribution.

\section{References}

Amt für Wirtschaft und Tourismus Graubünden 2011. Statistischer Atlas Graubünden. Available at: http://www.statistik.gr.ch (accessed 04/07/2011)

Arlettaz, R., P. Patthey, M. Baltic, T. Leu, M. Schaub, R. Palme \& S. Jenni-Eierman 2007. Spreading freeriding snow sports represent a novel serious threat for wildlife. Proceedings of the Royal Society B 274, 1614: 1219-1224.

Bundesamt für Umwelt 2009. Press release - Sport in freier Natur: Pilotprojekt für mehr Rücksichtnahme auf Wildtiere. Available at: http:/ / www.bafu.admin.ch/ dokumentation/medieninformation/00962/index. html?lang=de\&msg-id=25179 (accessed: $28 / 03 / 2009$ )

Beale, C.M. \& P. Monaghan 2004. Human disturbance: people as predation-free predators? Journal of Applied Ecology 41: 335-343.

Biosfera Val Müstair 2009. Charta 2010 - Regionaler Naturpark Biosfera Val Müstair. Available at: http:/ / 
www.biosfera.ch/pdf/RNPChartaBiosferaValMuestair07.01.2010.pdf (accessed 25/06/2011)

Bollmann, K., L. Jenni, N. Perrin \& W. Suter 2008. Naturschutzforschung am Auerhuhn in der Schweiz: eine Übersicht. Der Ornithologische Beobacbter 105 (1).

Bollmann, R. 2010. Besuchernutzung des Reitplatzes in Winterthur. Semesterarbeit Zürcher Hochschule für Angewandte Wissenschaften ZHAW, Wädenswil

Braunisch, V., P. Patthey \& R. Arlettaz 2011. Spatially explicit modeling of conflict zones between wildlife and snow sports: prioritizing areas for winter refuges. Ecological Applications 21 (3): 955-967.

Brenot, J.-F., M. Catusse \& E. Ménoni 1996. Effets de la station de ski de fond du Plateau de Beille (Ariège) sur une importante population de grand tétras Tetrao urogallus. Alauda 64: 249-260.

Freuler, B. \& M. Hunziker 2007. Recreation activities in protected areas: bridging the gap between attitudes and behavior of snowshoe walkers. Forest, Snow and Landscape Research 81 (1/2): 191-206.

Freuler, B. 2008. Management von Freizeitaktivitäten: Interventionen zur Beeinflussung von sozialen und ökologischen Nutzungskonflikten im Outdoorbereich. $\mathrm{PhD}$ Thesis. University of Zurich.

Gadient, R., H. Jenny \& U. Bühler 2010. Auerbubn-Konzept Graubünden. Amt für Jagd und Fischerei Graubünden \& Amt für Wald Graubünden. Chur.

Graf, R.F., K. Bollmann, S. Sachot, W. Suter \& H. Bugmann 2006. On the generality of habitat distribution models: a case study of capercaillie in three Swiss regions. Ecography 29: 319-328.

Ingold, P. 2005. Freizeitaktivitäten im Lebensraum der Alpentiere. Bern.

Laiolo, P. \& A. Rolando 2005. Forest bird diversity and ski slopes: a case of negative edge effect. Animal Conservation 7: 9-16.

Lamprecht, M., A. Fischer \& H.P. Stamm 2008. Das Sportverbalten der Schweizer Bevölkerung. Bundesamt für Sport BASPO.

Loppacher, D. 2008. Die Natur der Alpen aus Sicht der Profi- und Intensiv-Snowboarder - Reine Kulissenfunktion oder intensive Beziebung? MSc-Thesis University of Bern.

Marwijk van, R., B.H.M. Elands \& J. Lengkeek 2007. Experiencing nature: the recognition of the symbolic environment within research and management of visitor flows. Forest, Snow and Landscape Research 81 (1/2): 59-76.

Mönnecke, M., B. Schubert, K. Wasem, M. Gygax, B. Haller Rupf \& M. Amstutz 2005. Sportaktivitäten im Einklang mit Natur und Landschaft. Handlungsorientierte Lösungen für die Praxis. Rapperswil.

Mollet, P., B. Stadler \& K. Bollmann 2008. Aktionsplan Auerbubn Schwei . Bundesamt für Umwelt (BAFU), Schweizerische Vogelwarte und Schweizer Vogelschutz SVS/BirdLife Schweiz, Bern.

Müllner, A., E. Linsenmair \& M. Wikelski 2004. Exposure to ecotourism reduces survival and affects stress response in hoatzin chicks (Opisthocomus hoazin). Biological Conservation 118: 549-558.
Neue Zürcher Zeitung 2007. Träume in Weiss - Freeriding hat Suchtpotenzial. Available at: http://www. nzz.ch/magazin/reisen/traeume_in_weiss__freeriding_hat_suchtpotenzial_1.598105.html (accessed 07/10/2011)

Patthey, P., S. Wirthner, N. Signorell \& R. Arlettaz 2008. Impact of outdoor winter sports on the abundance of a key indicator species of alpine ecosystems. Journal of Applied Ecology 45 (6): 1704-1711.

Radue, G. 2004. Schneeschublaufen - eine Trendsportart. Laeufer, Konflikte, Lösungsansätze. Thesis University of Zurich.

Robin K., M. Bächtiger, A. Boldt, R.F. Graf, T. Liechti, T. Rempfler \& S. Suter 2010. Praxishilfeinstrument zur Ausscheidung von Wildrubezonen. Bundesamt für Umwelt, Abt. Artenmanagement, Sektion Jagd, Wildtiere und Waldbiodiversität.

Rolando, A., E. Caprio, E. Rinaldi \& I. Ellena 2007. The impact of high-altitude ski-runs on alpine grassland bird communities. Journal of Applied Ecology 44 (1): 210-219.

Sapolsky, R.M. 1992. Stress, the aging brain and the mechanisms of neuron death. Cambridge.

Schneeschuhprofi-Akademie 2007. Schneeschuhlaufen - Kurzurlaub für die Seele. Available at: http://www.movincoach.com/resources/Schneeschuhroutenkonzept\$252007-10-10.pdf (accessed: 07/10/2011)

Skov-Petersen, H. 2005. Feeding the Agents: Collecting parameters for agent-based models. In: Batty, S.E. (ed.), Computers in Urban Planning and Urban Management.

Sterl, P., R. Eder \& A. Arnberger 2010. Exploring factors influencing the attitude of ski tourers towards the ski touring management measures of the Gesäuse National Park. eco.mont 2 (1): 31-38.

Storch, I. 1995. Annual home ranges and spacing patterns of capercaillie in Central Europe. Journal of Wildlife Management 59 (2): 392-400.

Storch, I. 2000. Grouse: status survey and conservation action plan 2000-2004.

Suter, W., R.F. Graf \& R. Hess 2002. Capercaillie (Tetrao urogallus) and avian biodiversity: testing the umbrella-species concept. Conservation Biology 16: 778-788.

Taczanowska, K., A. Muhar \& A. Arnberger 2008. Exploring Spatial Behavior of Individual Visitors as Background for Agent-Based Simulation. In: Gimblett, R. \& H. Skov-Petersen (eds.), Monitoring, Simulation and Management of Visitor Landscapes: 159-174.

Thiel, D., E. Menoni, J.F. Brenot \& L. Jenni 2007. Effects of recreation and hunting on flushing distance of Capercaillie. Journal of Wildlife Management 71: 1784-1792.

Thiel, D., S. Jenni-Eiermann, V. Braunisch, R. Palme \& L. Jenni 2008. Ski tourism affects habitat use and evokes a physiological stress response in CapercaillieTetrao urogallus: a new methodological approach. Journal of Applied Ecology 45: 845-853. 
UNESCO 1996. Biosphere reserves: The Seville Strategy and the Statuary Framework of the World Network.

Walter, M. 2010. Signalisierte Schneeschurouten: Leitfaden für Anlage, Signalisation, Unterbalt und Betrieb. bfu - Beratungsstelle für Unfallverhütung. Bern.

Waegli, A. \& J. Skaloud 2007. Assessment of GPS/ MEMS-IMU Integration Performance in Ski Racing. European Navigation Congress ENC-GNSS, Geneva

Warnken, J. \& M. Blumenstein 2008. Monitoring visitor use in Australian terrestrial and marine protected areas: practical applications of technologies. Cooperative Research Centre for Sustainable Tourism.

Whittaker, D. \& R.L. Knight 1998. Understanding wildlife responses to humans. Wildlife Society Bulletin 26: 312-317.

Zeidenitz, C. 2005. Freizeitaktivitäten in der Schweiz - wegen oder gegen Natur und Landschaft? Eidg. Forschungsanstalt für Wald, Schnee und Landschaft WSL. Birmensdorf.

\section{Authors}

\section{Reto Rupf}

born 1966, professor of environmental planning at the Institute of Natural Resource Sciences IUNR at Zurich University of Applied Sciences ZHAW, Grüental, 8820 Wädenswil.

Research topics: outdoor recreation, visitor management, recreation ecology, modelling and simulation of human-wildlife interactions, parks, and EIA. rupf@zhaw.ch

\section{Martin Wyttenbach}

born 1978, environmental engineer FH. Teaches at the Institute of Natural Resource Sciences at IUNR / ZHAW.

Research topics: Outdoor recreation, visitor management, recreation ecology.wytt@zhaw.ch

\section{Daniel Köchli}

born 1969, associate professor for GIS and data visualization at IUNR / ZHAW.

Research topics: GIS modelling and simulation, data visualization, monitoring of spatial development. koda@zhaw.ch

\section{Martina Hediger}

born 1981, student of environmental engineering at ZHAW

Salome Lauber

born 1984, student of environmental engineering at ZHAW

\section{Pascal Ochsner}

born 1976, GIS research associate at the Institute of Natural Resource Sciences IUNR / ZHAW.

Research topics: Environmental geoinformatics and mobile mapping applications.

\section{Roland Graf}

born 1972, Dr. sc. ETH, lecturer, Wildlife and Landscape Management Unit, IUNR / ZHAW.

Research topics: wildlife ecology and management, conservation biology, spatial ecology, statistical and dynamical modelling.graf@zhaw.ch

Institute of Natural Resource Sciences, ZHAW Zurich University of Applied Sciences, Gruental, 8820 Waedenswil, Switzerland. 